\section{Agglutinins for complement-coated sheep erythrocytes}

Salivary 'IgA Immunoconglutinins', which reportedly bind both altered and native $\mathrm{C} 3$, have generated considerable interest $^{1.2}$. Unfortunately, the methods so far described for their purification are somewhat cumbersome, as they involve incubation of complementcoated sensitised sheep cells with saliva and subsequent elution of the 'IgA immunoconglutinins' with a chelating buffer. In our laboratory we have used a more classical approach, first fractionating parotid saliva on BioGel P100, then subfractionating each peak by DEAE-cellulose chromatography and testing the fractions for their reactions with complement and complementcoated cells (Fig. 1). (The details of the purification of salivary complementreactive factors will be published elsewhere $^{3}$.)

Our procedure has obvious advantages over that of Price et al. ${ }^{1}$. Since $\mathrm{Ca}^{2+}$-dependent IgA agglutinins for sheep cells are present in low titre in salivary secretions ${ }^{3,4}$, it is possible that those authors isolated secretory $\operatorname{IgA}$ attached not only to the human $\mathrm{C} 3$ on erythrocytes would tend to confuse qualitative and quantitative agglutination results. Furthermore, preliminary evidence suggests that salivary C3

\section{Matters arising}

Matters Arising is meant as a vehicle for comment and discussion about papers that appear in Nature. The originator of a Matters Arising contribution should initially send his manuscript to the author of the original paper and both parties should, wherever possible, agree on what is to be submitted. Neither contribution nor reply (if one is necessary) should be longer than 300 words and the briefest of replies, to the effect that a point is taken, should be considered.

and $\mathrm{C} 4$ agglutinins can be separated by DEAE subfractionation of the BioGel P100 peaks, with some salivary fractions demonstrating agglutinating activity for complement-coated sensitised erythrocytes and yet containing no detectable $\alpha$-chain antigens.

Using purified saliva fractions we have found that saliva contains agglu-

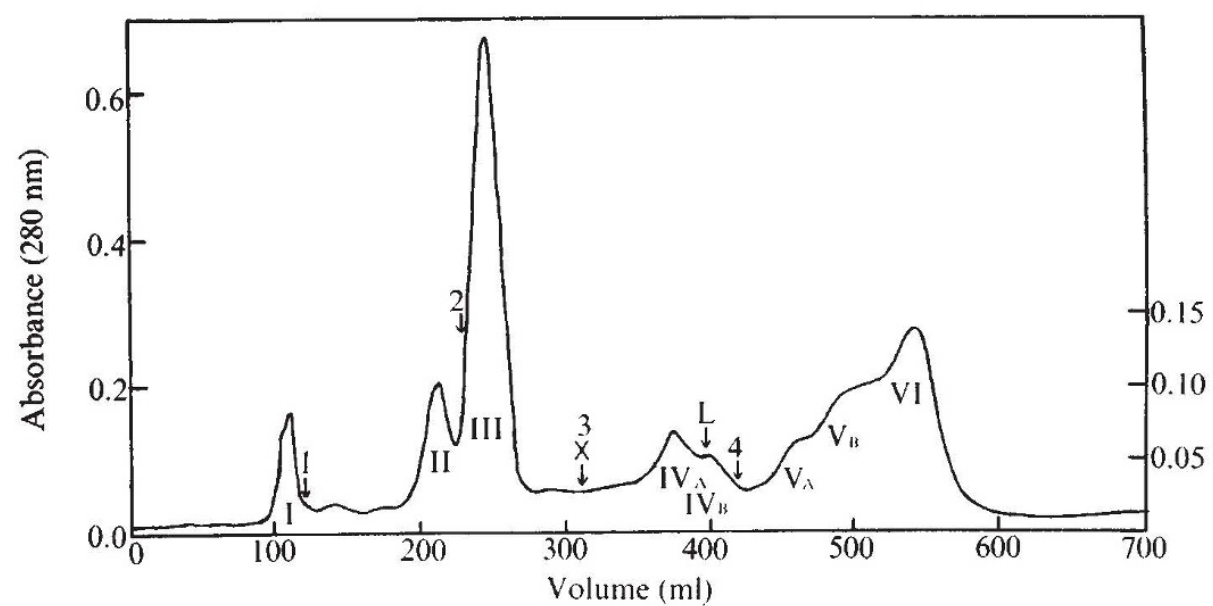

Fig. 1 Molecular sieve elution pattern of pooled parotid saliva chromatographed on BioGel P100. The elution buffer was $0.1 \mathrm{M}$ Tris- $0.2 \mathrm{M} \mathrm{NaCl}, p H 8.1$, with a flow rate of approximately $6 \mathrm{ml} \mathrm{h}^{-1}$. Column bed dimensions were $2.5 \times 96.5 \mathrm{~cm}$ with a volume of $475 \mathrm{ml}$. The saliva was dialysed against the column buffer using $3,000 \mathrm{~m}$.w. cutoff tubing (Thomas) before concentrating (Amicon apparatus. UMO5). Five millilitres of sample was added to the column. Salivary fractions (SFP) are labelled with Roman numerals. Numbered arrows refer to marker protein elution volumes; the proteins used were bovine albumin, chymotrypsinogen $\mathrm{A}$, insulin, and bovine trypsin inhibitor, for arrows 1-4 respectively. The arrow labelled $L$ represents the elution volume of human lysozyme, which was verified independently, and $X$ denotes the scale change position.

the sensitised erythrocytes but also to the erythrocytes themselves. Contamination with IgA antibodies and nonspecific agglutinins for sensitised tinins for IgG- and IgM-coated erythrocytes, located in SFPIV and SFPII respectively (Fig. 1). $\alpha$-chain antigens were found only in SFPI.
R. J. BOACKLE
K. M. Pruitt
H. Hugh Funenberg
R. L. Miller
E. A. Carsgo
W. F. HOWARI), JR

\section{Department of Basic and Clinical}

Immunology and Microbiology, Medical University of South Carolina. Charleston, South Carolina 29401

\footnotetext{
I Price, J. F., Williams, B. D., and Challacombe, S. J., Nature, 257, 146-147 (1975)

2 Williams, B. D., Slaney, J. M., Price, J. F., and Challacombe, S. J., Nature. 259, 52-53 (1976).

3 Boackle, R. J., Fudenberg, H. H., and Howard. W. F., J. dent. Res. (in the press). Tönder, O., and Larsen, B., Vox Sang, 24, 515.523
}

PrICE et al. REPLY.--The claim by Boackle et al. ${ }^{1}$ that their purification procedure "has obvious advantages over that of Price et al." is based on the erroneous assumption that calciumdependent IgA agglutinins to sheep erythrocytes are present in high titre in salivary secretions. In support of this statement they refer to the work of Tönder and Larsen ${ }^{2}$. The IgA agglutinins described by these authors, however, were not calcium dependent and were directed against rabbit rather than sheep erythrocytes. Agglutinins to sheep erythrocytes were looked for and found in only four of 17 samples of saliva, the highest titre being $1: 4$. Other workers have shown that agglutinins to sensitised sheep erythrocytes are present in low titre in adult saliva, but these agglutinins are not calcium dependent $^{3.4}$.

Contamination with $\operatorname{IgA}$ antibodies directed against the sensitised erythrocytes would therefore not occur when EDTA was used to elute the antiC3 antibodies from the cell surface. A simple way of preventing possible contamination by calcium-dependent agglutinins would be to incubate the saliva with sensitised erythrocytes before incubation with complement-coated cells.

Other workers who may be interested in studying these antibodies will decide whether EDTA elution from washed complement-coated erythrocytes (a procedure which may be performed in $2-3 \mathrm{~h}$ ) or fractionating on BioGel P100 and then subfractionating on DEAEcellulose is the less cumbersome method of purification.

Hospital for Sick Children and Guys Hospital, London, UK

Boackle, R. J., et al. Nuture, 264, 814 (1976)

2 Tünder, O., and Larsen, B., Vox Sang, 24. 515523 (1973).

Lachman, P. J and Thomson, R. A. Imumunotory.

18, 157 (1970).
4 Williams, B. D., Challacombe, S. J., Slaney, J. M. Lachminn, $\mathbf{P}$. J., and Lehner, $T$.. Clin. exp. Immun. 19, 423 (1973). 